\title{
Fruit drying traditions in Hungary
}

\author{
Surányi, D. \\ Fruit Research Station, Cegléd, Hungary, \\ author for correspondence: Surányi D. (suranyi.dezso@cefrucht.hu)
}

\begin{abstract}
Summary: Since the early eras of human history, the gathered products (roots, shoots, crops, fruits etc.), the environmental conditions of the preservation of the animals caught and the fishes; and accidental observations have been born new methods. Under cold and moderate climates, the effect of permanent frost, the use of ice as a means of curing as in dry, desert areas is the drying or exsiccation and the dehydration of salt. For convenience reasons, some of these methods have been forgotten, but the resurfacing of different fruits seems to resume. The short review gives an overview of the methods of drying used in the Carpathian Basin, especially among the Hungarian ethnic groups, which by the Hungarian ethnology thoroughly explored. The author attaches outstanding importance to the fruit-drying industry, because dried-ups at industrial scale are not equivalent to traditional low-fat lime scales. Excellent drying products are much better in terms of eating habits, with modern methods and small-scale production relatively easy to produce.
\end{abstract}

Surányi, D. (2017): Fruit drying traditions in Hungary. International Journal of Horticultural Science 23(1-4): 7-10. https://doi.org/10.31421/IJHS/23/1-4./1193

Key words: fruit drying, tradition, food, drying methods

\section{Introduction}

\section{The beginnings}

There are historical eras of drying in the World and of course it is also true for Hungary:

1. With collecting plant crops, it was almost time to preserve surplus with dredging (from the12th millennium $\mathrm{BC})$

2. After the Neolithic Revolution, it appears from the Middle East in the area of Europe $\left(4^{\text {th }}\right.$ millennium BC) and Southeast Asia (8th millennium BC)

3. Dry subtropical zones (Mediterranean) and mainly desert areas spontaneously offered the possibilities of drying

4. First dried fruits are known in many Middle Eastern and Middle Eastern sites in Europe (presumably more accidental cases)

5. Wild fruits from gathering are mostly easy to dry (yet few finds because they are consumed!)

6. In the early Greek and then Roman times, not only did they know some of their methods but also our written sources!

7. Theophrasthus, then Cato, and Palladius knew almost everything about assault as well as about extinction... (Surányi, 1985; Roach, 1985).

Drying was the oldest preservation process, it was used in the Chinese Empire, but ancient Greeks and Romans preserved much of their food. Our ancestors are most often sunburned on fire or on fire. Until the appearance of beet sugar, it was the only way to preserve the fruits (Bondor, 1983). For this purpose, dryers and baking ovens were used. The main advantages of the drying: it preserves the nutritional value, preservatives do not require it; can be used for months, in some cases for many years, half the space requirement, or a tenth of its fresh fruit.
Since the early days of the dawn, more and more sources are read about dried fruits; so far we have encountered some 35 species of dirt in the antiques (Mátyus, 1793) (Table 1).

The natural and floristic characteristics of the Carpathian Basin are excellent for the drying of fruit trees. Its predominance is proved by forestry, culinary and market sources. Outstanding evidence is from the work of Konrad Gesner 'Horti Germaniae', as well as by Antoine Mizald or Arnold Villanova's writings (together in Nadányi's book). János Lippay's description of 'Calendarum' (Lippay, 1661), 'Posoni kert' (Pressburg's Garden) (Lippay, 1664-1667) and János Nadányi 'Kerti dolgok leírása' (Garden Things) (Nadányi, 1669) summarizes the scientific and folk dessert experiences. We see Gesner's announcement as important for Hungarian dried fruits (Surányi, 1985).

\section{Prune as main product}

The dried plum is already included in the 1522 certificate, and in 1558 it is called 'Aszú Besztercei szilva'. Konrad Gesner (1552), Cordus Valerius (1561) also mentions that 'the Hungarian plum is held by pharmacies in the dry ... the dried plums are transported from Hungary ...' In Matthiolus'medical book (1554), the description of the „Dried plums from Pannonia and Transylvania" is described. Tabernaemontanus so writes: „We have been transported mainly to Germany, Switzerland, Austria, France, Poland and Bohemia, but sold in almost every pharmacy in Europe".

According to Veszelszki (1798), Hungarian or Besztercean prunes were already was well known to IIth King Andrew, who came to us from the Middle East or it maybe from the Eastern Steppes (see also: Györffy, 1911 and Nyilassy, 1957). The most famous of the 'Besztercei szilva' forms (Besztercean plums) are 'Magyarka', 'Kék szilva', 'Öszi aszaló', 'Házi szilva' or 'Hosszú szilva', known from the Szerémség, then 
Table 1. Nutritional values of fruit species (HÉRICS - TÓTH 1926, supplemented)

\begin{tabular}{|c|c|c|c|c|c|c|c|}
\hline Species & $\begin{array}{c}\text { Refraction, } \\
\%\end{array}$ & $\begin{array}{c}\text { Invert sugar, } \\
\% \\
\end{array}$ & $\begin{array}{c}\text { Acid, } \\
\%\end{array}$ & Pectin, \% & $\begin{array}{c}\text { Fiber, } \\
\%\end{array}$ & $\begin{array}{c}\text { Ash, } \\
\%\end{array}$ & $\begin{array}{c}\text { Water, } \\
\%\end{array}$ \\
\hline ananas & 12.8 & 11.9 & 0.71 & 1.8 & 0.4 & 0.5 & 85.9 \\
\hline apple & 13.6 & 8.1 & 0.71 & 3.2 & 1.2 & 0.4 & 84.4 \\
\hline apricot & 11.8 & 5.1 & 1.03 & 6.2 & 6.9 & 0.8 & 81.2 \\
\hline back mulberry & 14.1 & 9.2 & 1.86 & 2.1 & 0.9 & 0.6 & 84.7 \\
\hline banana & 13.9 & 11.4 & 0.25 & 2.6 & 0.4 & 0.9 & 88.2 \\
\hline blueberry & 9.1 & 7.2 & 0.97 & 0.5 & 3.9 & 0.5 & 86.2 \\
\hline cornel & 10.1 & 6.1 & 1.26 & 3.3 & 2.7 & 0.6 & 83.2 \\
\hline dewberry & h5.8 & 5.7 & 1.29 & 1.4 & 5.2 & 0.5 & 87.5 \\
\hline domestic plum & 12.4 & 8.4 & 1.03 & 4.9 & 5.2 & 0.6 & 83.3 \\
\hline elderberry & 26.8 & 4.7 & 0.58 & 3.5 & 2.9 & 1.1 & 92.2 \\
\hline fig & 17.4 & 15.5 & 0.08 & 1.6 & 2.8 & 0.6 & 78.9 \\
\hline gooseberry & 9.7 & 8.5 & 1.42 & 2.4 & 2.7 & 0.6 & 86.4 \\
\hline lemon & 9.2 & 0.4 & 2.45 & 0.3 & 2.1 & 0.4 & 85.2 \\
\hline mandarin & 11.9 & 8.8 & 0.82 & 2.2 & 0.5 & 0.6 & 87.6 \\
\hline medlar & 13.3 & 6.9 & $1 . .12$ & 3.2 & 2.8 & 0.8 & 82.7 \\
\hline melon & 4.3 & 5.1 & 0.12 & 2.9 & 5.5 & 0.3 & 94.6 \\
\hline orange & 10.1 & 7.8 & 1.33 & 2.3 & 2.6 & 0.4 & 86.3 \\
\hline peach & 12.7 & 4.5 & 0.79 & 6.2 & 5.7 & 0.7 & 90.2 \\
\hline pear & 11.1 & 7.9 & 0.33 & 3.9 & 0.1 & 0.3 & 84.7 \\
\hline quince & 13.9 & 7.4 & 0.93 & 3.6 & 1.9 & 0.6 & 86.4 \\
\hline raspberry & 7.4 & 3.9 & 1.29 & 1.4 & 6.1 & 0.4 & 86.2 \\
\hline redcurrant & 8.7 & 5.6 & 1.93 & 0.2 & 4.3 & 0.7 & 85.5 \\
\hline renclode & 10.1 & 6.1 & 0.97 & 2.6 & 0.6 & 0.5 & 80.8 \\
\hline rowan berry & 6.9 & 6.8 & 3.09 & 4.2 & 0.5 & 1.1 & 88.2 \\
\hline strawberry & 8.9 & 0.6 & 1.04 & 1.8 & 1.7 & 0.6 & 88.9 \\
\hline sweet cherry & 12.9 & 9.5 & 0.75 & 1.1 & 4.7 & 0.6 & 80.5 \\
\hline table grape & 17.6 & 5.6 & 0.77 & 1.1 & 2.2 & 0.4 & 79.2 \\
\hline watermelon & 6.4 & 5.1 & 0.11 & 2.8 & 0.8 & 0.4 & 91.3 \\
\hline wild rose & 21.8 & 3.8 & 1.29 & 4.9 & 9.8 & 3.3 & 73.9 \\
\hline
\end{tabular}

from Upper Tisza and Transylvania. Leibizer (1798) reads: „The 'Magyar' and 'Besztercei szilva' or Vasszilva is the first place to be considered as a valuable product of the country ... A splendid table fruit is transported far away." (Rapaics, 1940; Surányi, 1985).

There are more than 30 species of well-dried fruit species in the world, with the plum being a great tradition of apple, pear, sour cherry, apricot and figs. By new methods, special fruit treatments, as pears, peaches or sweet cherries are soaked in sugary, citric, sesquicar-bonate water before drying (Szabó, 1936; Dobrossy, 1968). Table 1 is more than just exotic fruit species but also known in the Carpathian Basin.

Historically, some areas of Szerémség, Zala, Ormánság, Transylvania, Upper Tisza were considered major dry places. No doubt the plum was the most important species, it changed to blue during the plumage of the Tisza or the Maros River (Surányi, 1990). Lippay (1667) has already written about these floodplain areas.

\section{Cultivars, methods and means}

But afterwards it was suitable for 'Agen', 'Nyári aszaló' and 'Fehér szilva' plums; 'Vajalma', 'Gravensteini' and 'Jonathan' apples; 'Kálmán', 'Vilmos' and 'Szegfü' pears (Surányi, 1984b) have been excellent raw materials; towards 'vadcseresznye' (bird cherry) and 'Ropogós cseresznye' sweet cherries or 'Arató' and 'Vörös meggy' cultivars (Surányi, 1984a). At the beginning of the last century, new varieties were expanded, for example, 'Elberta' and 'Champion' peaches, 'Rózsabarack' and 'Mandulabarack' apricots were also suitable (Surányi, 1990). Today, almost industrial-size fruit drying, which is not equal to conventional waxing, makes it possible to produce a weaker and better product than almost any kind of fruit (Surányi, 1992).

The ripe fruit on the thin skinned and late summer ends are usually dried on a day (drying wipe, basket, tray, etc.), cool, wet and dry overnight replacements, cups and trays to prevent mold growth. Rather, they were burnt on the autumn, as well as high-gloss and waxy fruit on fire (several constructions: traditional cooker, drying oven, drying house) (Balassa \& Ortutay, 1979; Paládi-Kovács, 2001). Earthy desiccants on the vineyards worked for many centuries, but they have not been traced to them today. Drying in furnaces, furnaces and drying rooms is still carried out today, with a drying mud in the drying room. After the bread was baked in the oven and in the farmhouse, the fruit of the cherry was placed in the oven room, and nowadays in the cooker ('sparhelt') and in its baking oven, on the top of a tile stove, sometimes in an electric-heated appliance or in a solar stove too (Rapaics, 1940; Balassa \& Ortutay, 1979; Paládi-Kovács, 2001). 


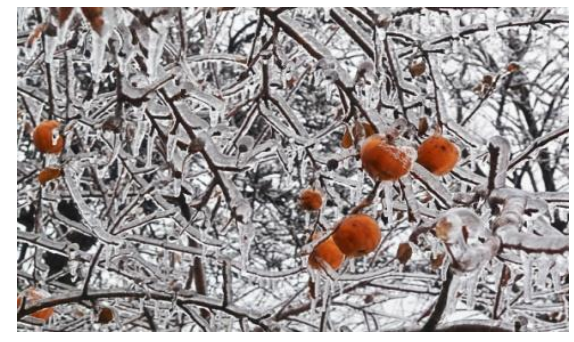

Figure 1. Idea: frozen apples?

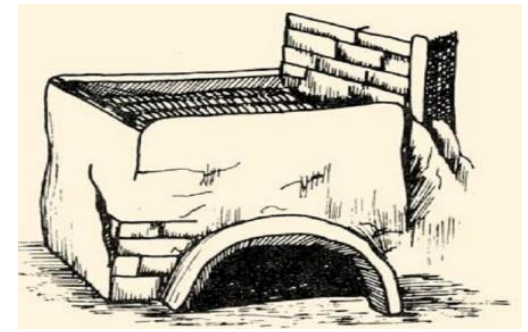

Figure 3. Simple drying equipment (Rétköz)

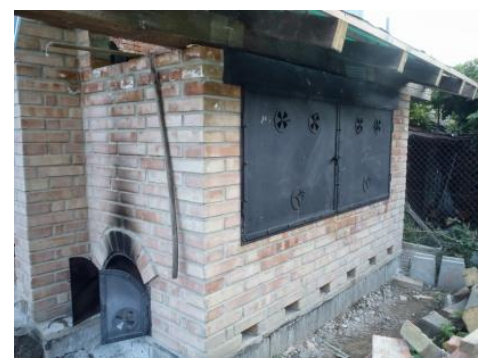

Figure 5b. Kiln dryer in Tisza Valley

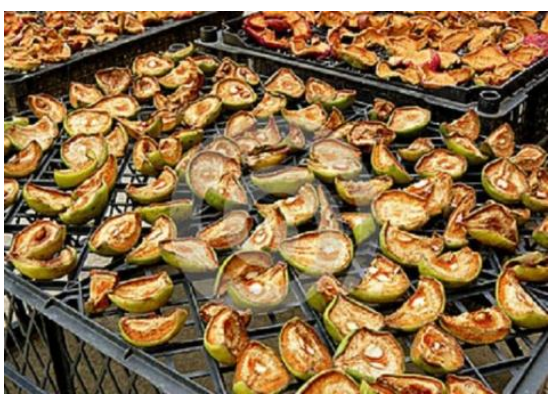

Figure $7 \boldsymbol{b}$. Pear slices drying on the sun

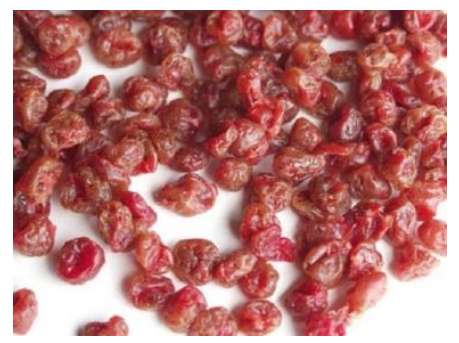

Figure 9a. Sweet cherry pitted dried fruits

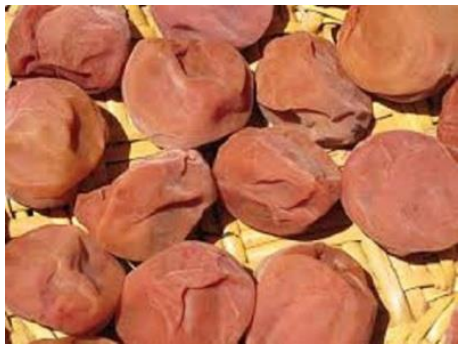

Figure 10b. Black dried plums

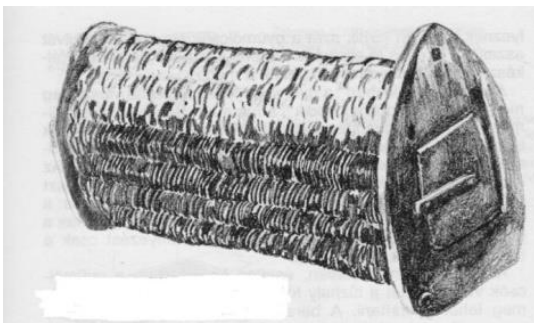

Figure 2a. Basket dryer ('kópic' - Kercaszomor)

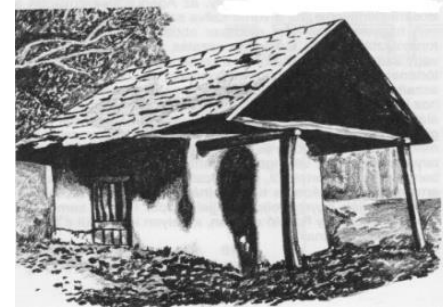

Figure 4. Straight dryer housing in Szatmár

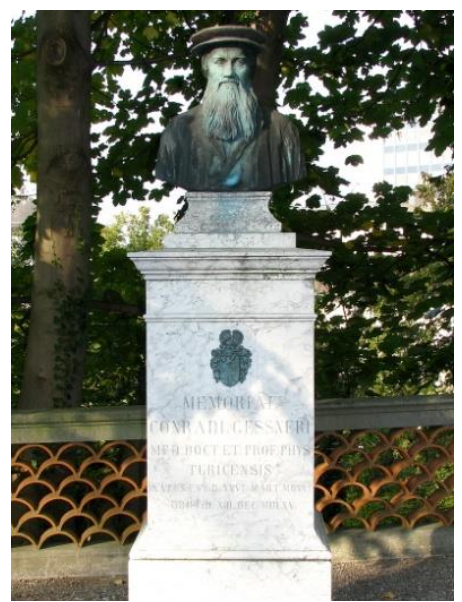

Figure 6. Konrad Gesner breast in Zurich Botanical Garden

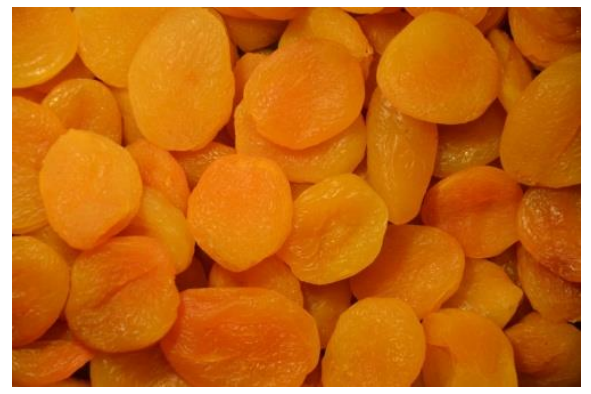

Figure 8a. Apricot dried fruits

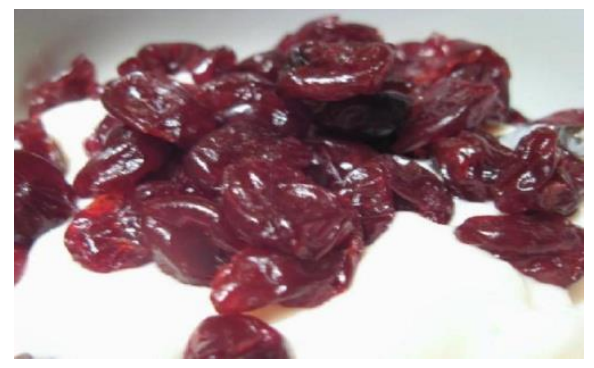

Figure 9 b. Sour cherry pitted dried fruits

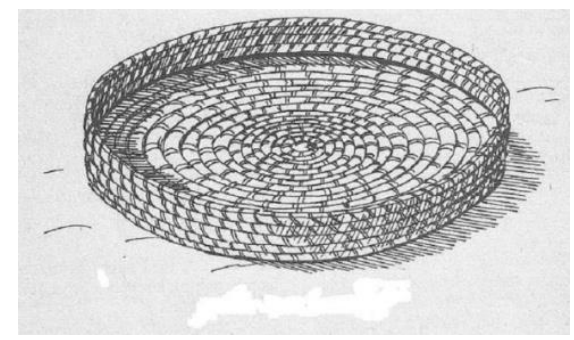

Figure 2b. Drying replacement ('párszárító' - Csongrád)

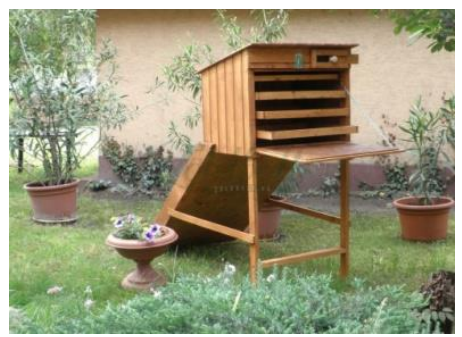

Figure 5a. Modern solar dryer

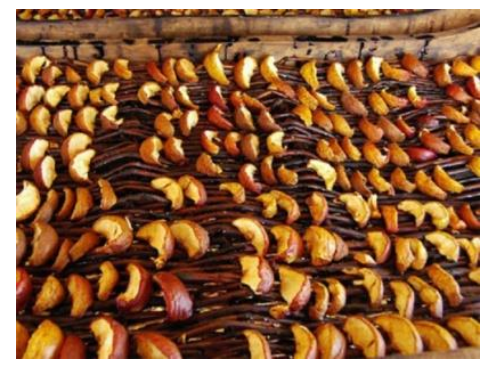

Figure 7a. Apple slices drying on the sun

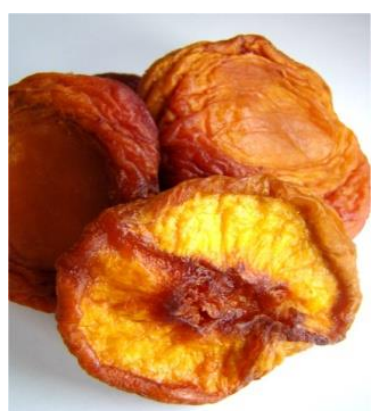

Figure $8 b$. Peach dried fruits

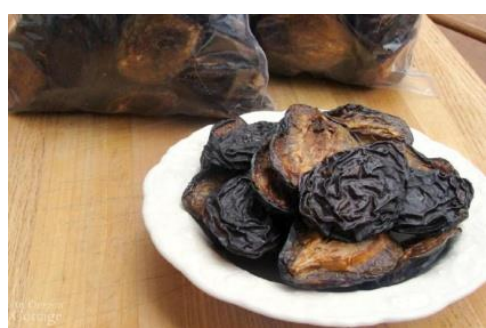

Figure 10a. Blue dried plums

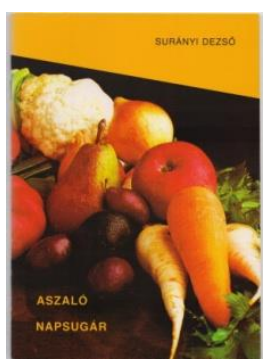

Figure 11.

Source: Figure 2, 3, 4: Magyar Néprajzi Lexikon; Figure 1, 5, 6, 7, 8, 9, 10, 11: author's photos 
In the smoky kitchen (Örség), excavated in the ground (Zemplén), or ashes in the oven-like ashlars houses form the archaic forms (Surányi, 1990); But the popularity of reform eating has brought urban desertification into fashion (Bondor, 1983; Surányi, 1985). Ashes are used to quickly dry hardwood fruits; otherwise 7 to 14 days will be required to make good quality and durable waxes. $6 \mathrm{~kg}$ apples, $6-7 \mathrm{~kg}$ pears, 5-6 kg (yellow and autumn) peach, $4-5 \mathrm{~kg}$ figs $3-4 \mathrm{~kg}$ plums and 2-3 $\mathrm{kg}$ cherries and sour cherry fruit can be obtained from $1 \mathrm{~kg}$ product (Surányi, 1990).

Many scrapers are subsequently dried at room temperature and stored hermetically to prevent mold being avoided. Dried fruit can absorb moisture; high quality product keeps its residual moisture and remains flexible. The finished dump is stored in a dry and cool place, in a canvas bag, in a glass, and sometimes sprinkled with pepper.

The finished waxes, 'bagolytüdő' (lung owl) or 'susina' were used mostly in fast food, or so-called 'nyálazó' (slippery) in the spinning room. We did not only meet fast food, but we did find it as a compost with a little bit of dessert. But now the meat stuffed with the dessert has also become a great ingredient.

In the Carpathian Basin history of the drying, other methods, which have been forgotten, have been recorded, such as pre-burning. Mostly autumn and winter pear (easily drenched on summer days) and for fruit, they pre-baked fruit slices; Zilahy (1892, cit. Hérics-Tóth, 1926), for example, recommended the pre-frying of 'Fojtós körte' and quince cultivars. However, in the case of fruits susceptible to over ripening, which are susceptible to appetite, only rapid drying was applied, avoiding caramelization.

The poorly digestible fruits, which were too juicy and high in polyphenols, were dried on raw wood tables, but in all other cases the fruit was protected from flies and wasps. Then the finished product, like the dried tobacco leaf, was frozen in the second half of the 19th century was a delicious matter was in Great Plain and Southland (Bácska, Szerémség). He was so oblivious that his Turkish name had disappeared from the public ('pasta').

\section{References}

Balassa, I. \& Ortutay, Gy. (1979): Magyar néprajz. Corvina, Budapest.

Bondor, A. (edit.) (1983): Erdei termékek gyüjtése és feldolgozása. Mezőgazdasági Kiadó, Budapest.
Dobrossy, I. (1969): Az aszalás mint konzerválási mód a Zemplén-hegység falvaiban. Ethnographia 80: 514-536.

Györffy, I. (1911): A szatmármegyei szilvaaszaló. Néprajzi Értesítő 12: 165-171.

Hérics-Tóth, J. (1926): Gyümölcsök és főzelékek konzerválásának kézikönyve (Az ipar és háztartás részére). Pátria Nyomda, Budapest.

Lippay, J. (1661): Calendarium. Cosmerovius Máté, Pozsony.

Lippay, J. (1664-1667): Posoni kert I-III. Cosmerovius Máté, Pozsony-Bécs.

Mátyus, I. K. (1793): Ó-és új diaetetica. Páldi István nyomdája, Kolozsvár.

Mohácsy, M. (1946): A gyümölcstermesztés kézikönyve. Athenaeum, Budapest.

Nadányi, J. (1669): Kerti dolgok leírása. Károli Gáspárné Nyomdája, Kolozsvár.

Nyilassy, J. (1957): Gyümölcsaszalás Zengővárkonyban. Néprajzi Közlemények 2: 165-171.

Ortutay, Gy. (edit.) (1979): Magyar Néprajzi Lexikon II. köt. Akadémiai Kiadó, Budapest.

Paládi-Kovács, A. (edit.) (2001): Magyar néprajz II. Gazdálkodás. Akadémiai Kiadó, Budapest.

Rapaics, R. (1940): A Magyar gyümölcs. Kir. Magyar Term. tud. Társulat, Budapest.

Roach, F. A. (1985): Cultivated fruits of Britain. Their origin and history. Basil Blackwill, Oxford - New York.

Surányi, D. (1984a): Népi tartósítás - A csonthéjasok nyári aszalása. Kertészet és Szőlészet 33 (31): 16-17.

Surányi, D. (1984b): Népi tartósítás - Az alma és a körte házi aszalása. Kertészet és Szőlészet 33 (33): 17.

Surányi, D. (1985): Kerti növények regénye. Mezőgazdasági Kiadó, Budapest.

Surányi, D. (1990): Aszaló napsugár. Téka Kiadó, Budapest.

Surányi, D. (1992): Magyar gyümölcs (manuscript). Kertészeti Egyetem, Budapest.

Szabó, B. (1934): A gyümölcs és konyhakerti termények feldolgozása. Pátria nyomda, Budapest.

Veszelszki, A. (1798): A növény-plánták országából való erdei és mezei gyüjtemény... Trattner Mátyás Nyomdája, Pest. 